\title{
INFERNO: a fire and emissions scheme for the UK Met Office's Unified Model
}

\author{
Stéphane Mangeon ${ }^{1,2}$, Apostolos Voulgarakis ${ }^{1}$, Richard Gilham ${ }^{2}$, Anna Harper ${ }^{3}$, Stephen Sitch ${ }^{4}$, and Gerd Folberth ${ }^{2}$ \\ ${ }^{1}$ Department of Physics, Imperial College London, London, UK \\ ${ }^{2}$ Met Office, FitzRoy Road, Exeter, EX1 3PB, UK \\ ${ }^{3}$ College of Engineering, Mathematics, and Physical Sciences, University of Exeter, Exeter, UK \\ ${ }^{4}$ College of Life and Environmental Sciences, University of Exeter, Exeter, UK
}

Correspondence to: Stéphane Mangeon (stephane.mangeon12@imperial.ac.uk)

Received: 8 February 2016 - Published in Geosci. Model Dev. Discuss.: 29 February 2016

Revised: 13 July 2016 - Accepted: 15 July 2016 - Published: 16 August 2016

\begin{abstract}
Warm and dry climatological conditions favour the occurrence of forest fires. These fires then become a significant emission source to the atmosphere. Despite this global importance, fires are a local phenomenon and are difficult to represent in large-scale Earth system models (ESMs). To address this, the INteractive Fire and Emission algoRithm for Natural envirOnments (INFERNO) was developed. INFERNO follows a reduced complexity approach and is intended for decadal- to centennial-scale climate simulations and assessment models for policy making. Fuel flammability is simulated using temperature, relative humidity $(\mathrm{RH})$ and fuel load as well as precipitation and soil moisture. Combining flammability with ignitions and vegetation, the burnt area is diagnosed. Emissions of carbon and key species are estimated using the carbon scheme in the Joint UK Land Environment Simulator (JULES) land surface model. JULES also possesses fire index diagnostics, which we document and compare with our fire scheme. We found INFERNO captured global burnt area variability better than individual indices, and these performed best for their native regions. Two meteorology data sets and three ignition modes are used to validate the model. INFERNO is shown to effectively diagnose global fire occurrence ( $R=0.66)$ and emissions $(R=0.59)$ through an approach appropriate to the complexity of an ESM, although regional biases remain.
\end{abstract}

\section{Introduction}

Fire is a key interaction between the atmosphere and the land surface (Bowman et al., 2009). Its impacts are wide-ranging: it influences forest succession (Bond and Keeley, 2005), is a tool for deforestation (van der Werf et al., 2009) and an important natural carbon source (Bowman et al., 2013), while it also provides a major natural hazard to humans through property and infrastructure destruction and air quality degradation (Johnston et al., 2012; Marlier et al., 2013). Biomass burning emissions are not only substantial in magnitude (Lamarque et al., 2010), but also drive the variability of atmospheric composition (Spracklen et al., 2007; Voulgarakis et al., 2010, 2015) and impact short-term climate forcing (Tosca et al., 2013).

There are feedbacks between fire and climate: lowhumidity conditions cause droughts, which enhance fire activity (Field et al., 2009), which, in turn, emits aerosols and trace gases (Akagi et al., 2011), influencing the abundances of radiatively active atmospheric constituents, cloud formation and lifetime, and in turn precipitation, and surface albedo (Voulgarakis and Field, 2015). Bistinas et al. (2014) showed global fire frequency is correlated with land-use, vegetation type and meteorological factors (dry days, soil moisture and maximum temperature) and that human presence tends to noticeably reduce fire activity (landmanagement, landscape fragmentation and urbanisation). Examining and quantifying such impacts and feedbacks is paramount to Earth system models (ESMs), yet to integrate vegetation fires presents many challenges as it intricately 
links multiple disciplines from ecology to atmospheric chemistry, physics and climate science.

Integration of fires into dynamic global vegetation models (DGVMs) was the first step towards fire within ESMs (e.g. Arora and Boer, 2005; Fosberg et al., 1999; Li et al., 2012; Pfeiffer et al., 2013; Sitch et al., 2003; Thonicke et al., 2001, 2010; Venevsky et al., 2002; Yue et al., 2014). Vegetation fires have been implemented into only a few ESMs, e.g. ECHAM (Lasslop et al., 2014) and the Community ESM (Li et al., 2013, 2014, p. 2).

Here, we present and evaluate the INteractive Fire and Emission algoRithm for Natural envirOnments (INFERNO) and its implementation. INFERNO is a necessarily simple parameterization that focuses on the large-scale occurrence of fires and is suitable for ESM application. The model uses a few key driving variables while retaining a broadly accurate parameterization for fire emissions. INFERNO's performance against observations and well-established and operationally relevant fire indices is presented.

\section{Model description}

\subsection{INFERNO}

INFERNO was constructed upon the simplified parameterization for fire counts proposed and evaluated for the presentday by Pechony and Shindell (2009), which was subsequently shown to provide a good estimate for large-scale fire variability over climatological timescales (Pechony and Shindell, 2010). In short, that parameterization uses monthly mean temperature, relative humidity $(\mathrm{RH})$ and precipitation to simulate fuel flammability. It also uses human population density and lightning to represent ignitions. To incorporate this parameterization within the Joint UK Land Environment Simulator (JULES; Best et al., 2011; Clark et al., 2011), several changes were applied. Upper layer soil moisture is used to represent precipitation memory while precipitation acts as a rapid fire deterrent. Vegetation density was replaced by fuel load index, dependent on leaf carbon and decomposable plant material (DPM), i.e. litter. Such a relationship with fine fuel and moisture was used in Thonicke et al. (2001). Furthermore, we developed a parameterization to obtain burnt area (BA), emitted carbon (EC) and fire emissions of different species $\left(E_{X}\right)$, and our fire diagnostics are made for each of the nine plant functional types (PFTs) in the current version of JULES (Harper et al., 2016).

Figure 1 summarises the mechanisms of INFERNO, and Fig. A1 in Appendix A illustrates the dependence of INFERNO on individual driving variables.

\subsubsection{Ignitions (I)}

INFERNO calculates ignitions in either one of three modes:

First, we can assume constant or ubiquitous ignitions, currently calibrated to a global average of $I_{\mathrm{T}}=$

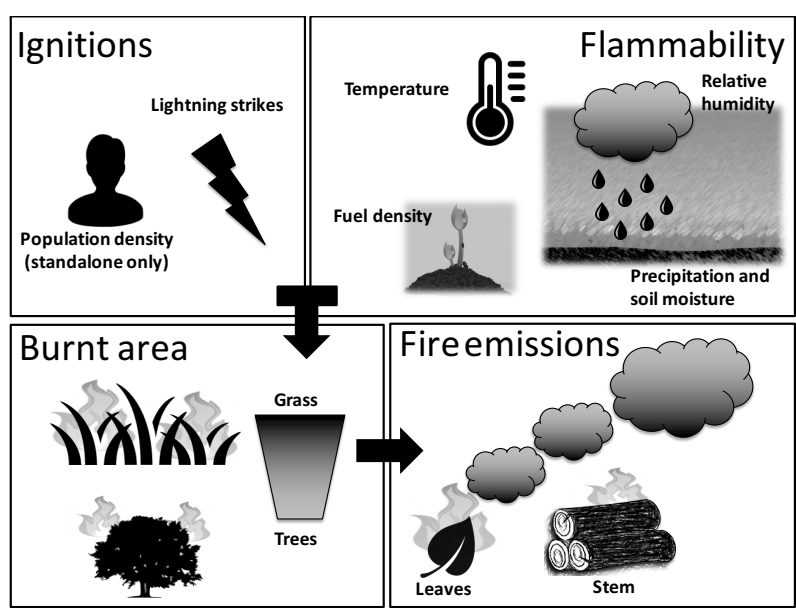

Figure 1. Schematic summarising the INteractive Fire and Emission algoRithm for Natural envirOnments (INFERNO) and its key components and behaviour. Ignitions can be accounted for in a variety of ways (see Sect. 2.1.1), meteorology influences flammability (see Sect. 2.1.2), while plant coverage influences burnt area (see Sect. 2.1.3), finally emissions are calculated according to leaf and stem carbon for each PFT (see Sect. 2.1.4).

1.67 ignitions km${ }^{-2}$ month $^{-1}$. This corresponds to 1.5 ignitions $\mathrm{km}^{-2}$ month $^{-1}$ due to humans $\left(I_{\mathrm{A}}\right)$, heuristically determined, and 0.17 ignitions km ${ }^{-2}$ month $^{-1}$ natural ignitions due to lightning $\left(I_{\mathrm{N}}\right)$, derived from the multi-year annual mean of 2.7 strikes km${ }^{-2}$ year $^{-1}$ (Huntrieser et al., 2008) assuming that $75 \%$ of strikes are cloud-to-ground (Prentice and Mackerras, 1977). This mode inherently suppresses the variability in fires due to any anthropogenic or natural ignition changes (Pechony and Shindell, 2009, 2010).

Second, human ignitions and suppressions can be assumed to remain constant at the global mean value mentioned above $\left(I_{\mathrm{A}}=1.5\right.$ ignitions km${ }^{-2}$ month $\left.^{-1}\right)$; however cloudto-ground lightning strikes may vary and, in addition, each strike is assumed to start a fire. This mode accounts for natural variability in fire ignitions, which can be simulated within an ESM, or prescribed from observations.

Third, varying human ignitions and suppressions and varying natural ignitions (cloud-to-ground lightning strikes, as in mode 2). This was the original ignition approach in Pechony and Shindell (2009), which was left unchanged and is detailed below. In this ignition mode, anthropogenic ignition and suppression depends on population density (PD), as proposed by Venevsky et al. (2002).

$I_{\mathrm{A}}=k(\mathrm{PD}) \mathrm{PD} \alpha$

$\mathrm{PD}$ is in units of people $\mathrm{km}^{-2}$, and $k(\mathrm{PD})=6.8 \times \mathrm{PD}^{-0.6}$ is a function that represents the varying anthropogenic influence on ignitions in rural vs. urban environments. The parameter $\alpha=0.03$ represents the number of potential ignition sources per person per month per $\mathrm{km}^{2}$. Both natural and anthropogenic ignitions have the potential to be suppressed by 
humans, such that the fraction of fires not suppressed is

$f_{\mathrm{NS}}=7.7\left(0.05+0.9 \times e^{-0.05 \mathrm{PD}}\right)$.

Equation (2) includes a scaling factor of 7.7 (Pechony and Shindell, 2009) originally introduced to calibrate the number of fires to MODIS observations. Total ignitions $\left(I_{\mathrm{T}}\right.$, in ignitions $\mathrm{m}^{-2} \mathrm{~s}^{-1}$ ) can be represented as (Eq. 3)

$I_{\mathrm{T}}=\left(I_{\mathrm{N}}+I_{\mathrm{A}}\right) f_{\mathrm{NS}} /\left(8.64 \times 10^{10}\right)$.

Here, $f_{\mathrm{NS}}=1$ for mode 1 and 2 , and follows Eq. (2) for mode 3. Dividing by $8.64 \times 10^{10}$ converts ignitions $\mathrm{km}^{-2}$ month $^{-1}$ to ignitions $\mathrm{m}^{-2} \mathrm{~s}^{-1}$.

\subsubsection{Flammability $(F)$}

We adapt the Pechony and Shindell (2009) scheme for flammability to function interactively within an ESM (see Eq. 6). Starting from the saturation vapour pressure $\left(e^{*}\right.$, Eq. 4; Goff and Gratch, 1946) and its temperature dependence, we introduce a fuel load index (FLPFT, Eq. 5) as well as $\mathrm{RH}$, precipitation and soil moisture in order to obtain flammability (Eq. 6). The land surface model (JULES) determines soil moisture content $(\theta)$ and fuel load (DPM C $_{\mathrm{C}}$ and Leaf $_{\text {C,PFT }}$.

$$
\begin{aligned}
\log _{10}\left(e^{*}\right) & =a\left(\frac{T_{\mathrm{s}}}{T}-1\right)+b \log _{10}\left(\frac{T_{\mathrm{S}}}{T}\right) \\
& +c\left(10^{d\left(1-\frac{T_{\mathrm{S}}}{T}\right)}-1\right)+f\left(10^{h^{\left(\frac{T_{\mathrm{S}}}{T}-1\right)}}-1\right)
\end{aligned}
$$

As illustrated in Eq. (4), INFERNO utilises temperature ( $T$ in $\mathrm{K}$, at $1.5 \mathrm{~m}$ height). The Goff-Gratch equation (Eq. 4) uses the constants: $a=-7.90298, b=5.02808, c=-1.3816 \times$ $10^{-7}, d=11.344, f=8.1328 \times 10^{-3}, h=-3.49149$ and the water boiling point temperature $T_{\mathrm{S}}=373.16 \mathrm{~K}$.

$$
F L_{P F T}=\left\{\begin{array}{l}
\begin{array}{l}
1 \text { for Fuel }_{\text {high }}<\left(\mathrm{DPM}_{\mathrm{C}}+\text { Leaf }_{\mathrm{C}, \mathrm{PFT}}\right) \\
\text { (DPM } \left._{\mathrm{C}}+\text { Leaf }_{\mathrm{C}, \mathrm{PFT}}\right)- \text { Fuel low }_{\text {low }}
\end{array} \\
\begin{array}{l}
\text { Fuel }_{\text {high }}-\text { Fuel }_{\text {low }} \\
\text { for Fuel low }_{\text {low }} \leq\left(\mathrm{DPM}_{\mathrm{C}}+\text { Leaf }_{\mathrm{C}, \mathrm{PFT}}\right) \\
\leq \text { Fuel }_{\text {high }} \\
0 \text { for Fuel low }_{\text {low }}>\left(\mathrm{DPM}_{\mathrm{C}}+\text { Leaf }_{\mathrm{C}, \mathrm{PFT}}\right)
\end{array}
\end{array}\right.
$$

Equation (5) shows FLPFT is taken as the PFT-specific leaf carbon (Leaf $_{\mathrm{C}, \mathrm{PFT}}$, aboveground) plus the carbon within DPM $\left(\mathrm{DPM}_{\mathrm{C}}\right)$. DPM is a soil carbon pool of which we assume $70 \%$ is available to fires, i.e. near surface (DPM is shared across all PFTs). FL scales linearly between 0 (at a threshold of Fuel $\mathrm{l}_{\text {low }}=0.02 \mathrm{kgC} \mathrm{m}^{-2}$ ) and 1 (at a threshold of Fuel $_{\text {high }}=0.2 \mathrm{kgC} \mathrm{m}^{-2}$ ). Similar approaches to represent fuel availability within fire parameterizations have commonly been adopted (Arora and Boer, 2005; Li et al., 2012;
Thonicke et al., 2010).

$$
F_{\mathrm{PFT}}=\left\{\begin{array}{l}
e^{*} e^{-2 R} \mathrm{FL}_{\mathrm{PFT}}(1-\theta) \text { for } \mathrm{RH}_{\mathrm{up}}<\mathrm{RH} \\
e^{*} \frac{\mathrm{RH}-\mathrm{RH}_{\text {low }}}{\mathrm{RH}_{\mathrm{up}}-\mathrm{RH}_{\mathrm{low}}} e^{-2 R} \mathrm{FL}_{\mathrm{PFT}}(1-\theta) \\
\quad \text { for } \mathrm{RH}_{\text {low }} \leq \mathrm{RH} \leq \mathrm{RH}_{\text {high }} \\
0 \text { for } \mathrm{RH}_{\text {low }}>\mathrm{RH}
\end{array}\right.
$$

$\mathrm{RH}$ is the relative humidity (\%) and $R$ is the precipitation rate $\left(\mathrm{mm} \mathrm{day}^{-1}\right)$. The influence of $\mathrm{RH}$ scales between (and is bound by) 0 (at a threshold of $\mathrm{RH}_{\text {low }}=10 \%$ ) and 1 (at a threshold of $\mathrm{RH}_{\text {up }}=90 \%$ ). We then adapt the formula by replacing a vegetation index dependent on leaf area index (LAI) with the fuel load index (FL). Finally, flammability $\left(F_{\mathrm{PFT}}\right)$ is dependent on upper-level (down to $0.1 \mathrm{~m}$ ) soil moisture: $\theta$ is the unfrozen soil moisture as a fraction of saturation. The individual importance of these variables to our model is illustrated in Fig. A1.

\subsubsection{Burnt area (BA)}

Our approach is to associate an average burnt area per fire to each PFT, effectively decoupling the fire-spread stage from local meteorology and topography, which is typically not resolved in the relatively coarse grid of an ESM. An average burnt area $(\overline{\mathrm{BA}} \mathrm{PFT})$ was heuristically determined for each PFT: $0.6,1.4$ and $1.2 \mathrm{~km}^{2}$ for trees, grass and shrubs, respectively, such that grass and shrubs will fuel larger fires than trees. Sub-categories of trees, grass and shrubs are not differentiated. Observational evidence supports that the land cover type is an efficient way to characterise fires, which tend to be larger in grasslands than in forests (Chuvieco et al., 2008; Giglio et al., 2013). The BA is then calculated following Eq. (7):

$\mathrm{BA}_{\mathrm{PFT}}=I_{\mathrm{T}} F_{\mathrm{PFT}} \overline{\mathrm{BA}} \overline{\mathrm{PFT}}$.

Here, $\mathrm{BA}_{\mathrm{PFT}}$ is the burnt area (fraction of PFT cover burnt per second) for each PFT; meanwhile the number of ignitions times the flammability $\left(I_{\mathrm{T}} F_{\mathrm{PFT}}\right)$ represents the number of fires.

Inferring burnt area from number of fires in this manner stands out from other fire models that utilise wind speed (Arora and Boer, 2005; Thonicke et al., 2010; Li et al., 2012), effectively modelling the fire rate of spread. Wind is key to the modelling of individual fires; yet implementing wind effectively within fire models designed for the relatively coarse grid of ESMs was found to be problematic (Lasslop et al., 2014, 2015). Conversely, Hantson et al. (2014) found global fire size was mostly influenced by precipitation, aridity and human activity (population density and croplands).

\subsubsection{Emitted carbon (EC)}

To account for the wetness of fuel in INFERNO, combustion completeness (the fraction of biomass exposed to a fire that was volatised) scales linearly with soil moisture (as a fraction 
of saturation) with different upper and lower boundaries for leaf and stem carbon.

$$
\begin{aligned}
\mathrm{EC}_{\mathrm{PFT}} & =\mathrm{B} A_{\mathrm{PFT}} \sum_{\text {leaf,stem }}^{i}\left(\mathrm{CC}_{\mathrm{min}, i}\right. \\
& \left.+\left(\mathrm{CC}_{\mathrm{max}, i}-\mathrm{CC}_{\min , i}\right)(1-\theta)\right) \mathrm{C}_{i}
\end{aligned}
$$

Equation (8) shows how the PFT-specific EC (in $\mathrm{kgC} \mathrm{m}^{-2} \mathrm{~s}^{-1}$ ) is computed. BA is the burnt area (fraction $\left.\mathrm{s}^{-1}\right), \mathrm{CC}_{\min }$ and $\mathrm{CC}_{\max }$ are the minimum and maximum combustion completeness for both leaves $\left(\mathrm{CC}_{\min }=0.8\right.$ and $\left.\mathrm{CC}_{\max }=1.0\right)$ and stems $\left(\mathrm{CC}_{\min }=0.0\right.$ and $\left.\mathrm{CC}_{\max }=0.4\right)$ and $\mathrm{C}_{i}$ is the carbon stored in each PFT's leaves or stems $\left(\mathrm{kgC} \mathrm{m}^{-2}\right)$. The parameters used for combustion completeness $\left(\mathrm{CC}_{\min }\right.$ and $\left.\mathrm{CC}_{\max }\right)$ are similar to the Global Fire Emission Database (GFED; van der Werf et al., 2010), albeit with lower minimum combustion of stems $(0.0$ as opposed to 0.2). Nevertheless, GFED uses a more complex representation of moisture across multiple fuel types and only accounts for fires that were observed. In comparison, our scheme only relies on soil moisture and was much more sensitive to minimum combustion, such that the contribution from moist forested areas (e.g. rainforests) needed to be reduced by increasing the impact of soil moisture (reducing stems' $\mathrm{CC}_{\min }$ ).

\subsubsection{Emitted species $\left(E_{X}\right)$}

There has been a significant amount of work on estimating emission factors (EFs) across fire biomes (such as savannahs, boreal forest, etc.). This was synthesised in Akagi et al. (2011) as well as Andreae and Merlet (2001) and its updates. Updated EFs for Akagi et al. (2011) were not used in this version of INFERNO. To convert biome-specific EFs to PFT-specific EFs, each PFT was linked to a fire biome (see Table A1). INFERNO uses these to estimate emissions (Eq. 9).

$$
E_{X, \mathrm{PFT}}=\mathrm{EC}_{\mathrm{PFT}} \mathrm{EF}_{X, \mathrm{PFT}} /[\mathrm{C}]
$$

Here, $E_{X}$ is the amount of species $X$ emitted by fires (in $\mathrm{kg} \mathrm{m}^{-2} \mathrm{~s}^{-1}$ ), EC is the emitted carbon (in $\mathrm{kgC} \mathrm{m}^{-2} \mathrm{~s}^{-1}$ ), $\mathrm{EF}_{X}$ is the PFT-specific emission factor (see Table 1) (in $\mathrm{kg}$ of species emitted per $\mathrm{kg}$ of biomass burnt) and [C] is the dry biomass carbon content, which we assume as $50 \%$ (a common simplification; Lamlom and Savidge, 2003). INFERNO currently provides emissions for basic trace gases: $\mathrm{CO}_{2}, \mathrm{CO}$, $\mathrm{CH}_{4}, \mathrm{NO}_{x}, \mathrm{SO}_{2}$ and aerosols: organic carbon (OC) and black carbon (BC).

\subsection{Implementation within JULES}

INFERNO is currently implemented within the JULES (Best et al., 2011; Clark et al., 2011) its carbon fluxes and vegetation dynamics. The results shown here used JULES v4.3.1 and INFERNO will be included in JULES from version 4.5 onwards. INFERNO utilises soil moisture (see Eqs. 6, 8), which JULES calculates as the balance between precipitation (following the scheme for rainfall interception in Dolman and Gregory, 1992) and extraction by evapotranspiration and runoff (Cox et al., 1999; Best et al., 2011). JULES has four soil layers, and INFERNO uses the top layer unfrozen soil moisture ( 0 to $0.1 \mathrm{~m}$ depth). Note that in its current state, JULES does not associate carbon pools with depths; hence, it is not possible, for example, to access only the top-most DPM. The vegetation dynamics and litter carbon used obey the TRIFFID DGVM (Cox, 2001). Fractional coverage of PFTs in any grid cell is based on competition for resources (light and water), governed by Lotka-Volterra competition equations and based on a tree-shrub-grass dominance hierarchy (Cox, 2001).

In JULES, vegetation carbon content is determined by the balance between photosynthesis, respiration and litterfall. Within JULES, TRIFFID (the Top-down Representation of Foliage and Flora Including Dynamics; Cox, 2001) predicts changes in biomass and the fractional coverage of nine PFTs (Table A1) based on accumulated carbon fluxes and heightbased competition, where the tallest trees have first access to space (Harper et al., 2016). Vegetation can grow in height, and the carbon in leaves, roots, and wood is related allometrically to the "balanced LAI", $L_{\mathrm{b}}(\mathrm{Cox}, 2001) . L_{\mathrm{b}}$ is the seasonal maximum LAI and a function of plant height. Within INFERNO, leaf carbon $\left(\mathrm{Leaf}_{\mathrm{C}}\right.$, used for calculating FD and emissions) is

Leaf $_{\mathrm{C}}=\sigma_{1} L_{\mathrm{b}}$

Meanwhile, wood carbon $\left(\right.$ Wood $_{\mathrm{C}}$, which affects emissions), is calculated as

$\operatorname{Wood}_{\mathrm{C}}=a_{\mathrm{wl}} L_{\mathrm{b}}^{b_{\mathrm{wl}}}$.

PFT dependent parameters ( $\sigma_{1}$, the specific leaf density, $a_{\mathrm{wl}}$, the allometric coefficient and $b_{\mathrm{wl}}$, the allometric exponent) are given in Table A1.

When using JULES in its standalone version, INFERNO can use inputs of population density (in people $\mathrm{km}^{-2}$ ) and cloud-to-ground lightning flash rates (in flashes $\mathrm{km}^{-2}$ month $^{-1}$ ) from ancillary data sets. Interestingly, lightning can be interactively simulated in atmospheric models (not population), although this will not be explored in this paper. Similarly, meteorology needs to be prescribed and is then interpolated from its native temporal resolution to the model's time step. Although designed to be integrated within an ESM, the capability to run INFERNO only with JULES is particularly useful for present-day comparison with observations, and to dissociate causes of biases in results. In its current early state, INFERNO provides a diagnostic tool, it does not remove carbon from vegetation nor does it lead to tree mortality. 
Table 1. INFERNO's emission factors per PFT created from the emission profiles in Akagi et al. (2011), such that each PFT was attributed a fire biome (see Table A1). This method of attributing emission factors to PFTs is similar to that presented in Thonicke et al. (2010), and can be extended to include all species of trace gases and aerosols compiled in Akagi et al. (2011).

\begin{tabular}{lrrrrrrr}
\hline Emission factors $\left(\mathrm{g} \mathrm{kg}^{-1}\right)$ & $\mathrm{CO}_{2}$ & $\mathrm{CO}$ & $\mathrm{CH}_{4}$ & $\mathrm{NO}_{x}$ & $\mathrm{SO}_{2}$ & $\mathrm{OC}$ & $\mathrm{BC}$ \\
\hline Broadleaf evergreen tree (tropical) & 1643 & 93 & 5.07 & 2.55 & 0.40 & 4.71 & 0.52 \\
Broadleaf evergreen tree (temperate) & 1637 & 89 & 3.92 & 2.51 & $0.40^{\mathrm{a}}$ & $8.2^{\mathrm{b}}$ & $0.56^{\mathrm{b}}$ \\
Broadleaf deciduous tree & 1643 & 93 & 5.07 & 2.55 & 0.40 & 4.71 & 0.52 \\
Needleleaf evergreen tree & 1637 & 89 & 3.92 & 2.51 & $0.40^{\mathrm{a}}$ & $8.2^{\mathrm{b}}$ & $0.56^{\mathrm{b}}$ \\
Needleleaf deciduous tree & 1489 & 127 & 5.96 & 0.90 & $0.40^{\mathrm{a}}$ & $8.2^{\mathrm{b}}$ & $0.56^{\mathrm{b}}$ \\
C3 grass & 1637 & 89 & 3.92 & 2.51 & $0.40^{\mathrm{a}}$ & $8.2^{\mathrm{b}}$ & $0.56^{\mathrm{b}}$ \\
C4 grass & 1686 & 63 & 1.94 & 3.9 & 0.48 & 2.62 & 0.37 \\
Evergreen shrub & 1637 & 89 & 3.92 & 2.51 & $0.40^{\mathrm{a}}$ & $8.2^{\mathrm{b}}$ & $0.56^{\mathrm{b}}$ \\
Deciduous shrub & 1489 & 127 & 5.96 & 0.90 & $0.40^{\mathrm{a}}$ & $8.2^{\mathrm{b}}$ & $0.56^{\mathrm{b}}$ \\
\hline
\end{tabular}

${ }^{a}$ Profile not available in Akagi et al. (2011); therefore, we mimic tropical forests. ${ }^{b}$ from Andreae and Merlet (2001).

\subsection{Fire weather indices}

Three other well-established daily fire indices are also available within JULES. These indices have been used for several decades to help plan operational response to wildfires on numerical weather predictions (NWP) timescales. Although unit-less and ill-defined risk-based quantities, comparison to INFERNO is still useful for understanding the results in the context of practically established metrics.

The Canadian Fire Weather Index (Forestry Canada, 1992; Van Wagner and Pickett, 1985) consists of six components, calculated from basic meteorological parameters. Three are fuel moisture codes designed to represent the drying of different fuel types, their characteristics are displayed in Table A2. Two intermediate quantities, the Initial Spread Index and the build-up index are calculated from these, and are in turn used to yield the final Fire Weather Index (FWI):

$\mathrm{FWI}=\left\{\begin{array}{l}e^{2.72(0.434 \ln B)^{0.647}}, B>1 \\ B, B \leq 1\end{array}\right.$,

where $B=0.1$ ISI FD with ISI (Initial Spread Index) and FD the fuel density. We refer to the original publications for detailed equations for the complex Canadian FWI and each of its components.

The McArthur Forest Fire Danger Index (FFDI; Noble et al., 1980; Sirakoff, 1985) was developed for use in Australia. Simpler in its formulation than the Canadian index, it consists of a drought component modified by the local temperature, humidity and wind speed. The calculation of the drought component depends on the soil moisture deficit (the amount of water needed to restore the soil moisture content of the top $800 \mathrm{~mm}$ of soil to $200 \mathrm{~mm}$ ), which is related to the JULES soil moisture.

The FFDI ( $\left.F_{\text {McArthur }}\right)$ is given by

$F_{\text {McArthur }}=1.275 D^{0.987} e^{\frac{T}{29.5858}-\frac{H}{28.9855}+\frac{W}{42.735}}$, where $T$ is the daily maximum temperature, $H$ the daily minimum RH and $W$ the daily mean wind speed. $D$ is the drought factor, given by

$D=\frac{0.191(I+104)(N+1)^{1.5}}{3.25(N+1)^{1.5}+R-1}$,

where $N$ is the number of days since the last rain, $R$ the total rain in the most recent day with rain and $I$ the amount of rain needed to restore the soil moisture content to $200 \mathrm{~mm}$ in the top $800 \mathrm{~mm}$ of soil.

Finally, the Nesterov index (Nesterov, 1949) is the simplest fire index implemented in JULES. It uses only the daily mean temperature, mean daily dew point (or suitable substitute), daily total precipitation and the previous day's index. The index is incremented daily, unless daily precipitation exceeds $3 \mathrm{~mm}$, in which case it is reset:

$N=\left\{\begin{array}{l}N_{0}+T(T-D) P<3 \mathrm{~mm} \\ 0, P \geq 3 \mathrm{~mm}\end{array}\right.$,

where $T$ is the mean daily temperature, $D$ the mean daily dew point, $P$ the daily total precipitation and $N_{0}$ the previous day's index. The Nesterov index is a key component for other fire models (Venevsky et al., 2002; Thonicke et al., 2010).

\section{Model configuration}

Monthly lightning data were obtained from LIS-OTD (Lightning Imaging Sensor - Optical Transient Detector) observations for 2013 (Christian et al., 2003) and was recycled for every year in the simulation. These detections were converted to cloud-to-ground strikes using the relationship presented in Prentice and Mackerras (1977). Land use and population density were obtained from the HYDE data set (Hurtt et al., 2011) and then linearly interpolated to create inter-annually varying data. Finally, annual $\mathrm{CO}_{2}$ concentrations, which affect vegetation dynamics, were prescribed as a global aver- 

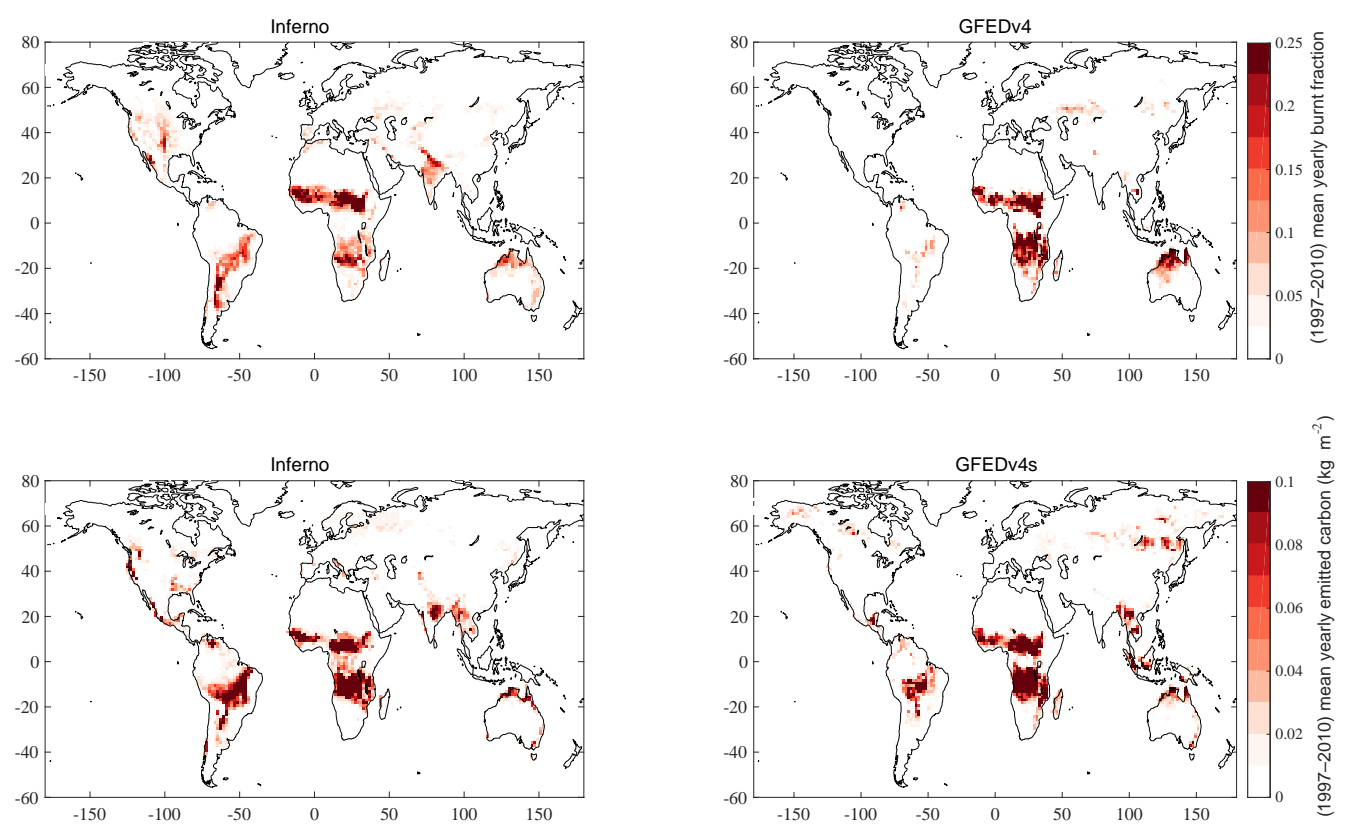

Figure 2. 1997-2010 mean yearly burnt fraction (above) and emitted carbon (below, in $\mathrm{kg} \mathrm{m}^{-2}$ ). Shown for INFERNO on the left (with CRU-NCEP meteorology and interactive ignitions; ignition mode 3) and for GFED on the right.

age following the data set prepared for the global carbon budget (Le Quéré et al., 2015).

To test the sensitivity to the meteorological input, JULES simulations were driven by meteorology from both CRUNCEP (Climate Research Unit and National Center for Environmental Prediction) v5 (https://crudata.uea.ac.uk/cru/data/ ncep/), and WFDEI (Weedon et al., 2014) with precipitation from the GPCC (Schneider et al., 2013). Both data sets were used on a 6-hourly basis.

Outside of these driving variables, JULES was configured according to the TRENDY project (Sitch et al., 2015; Peng et al., 2015); 100-year spin-up was performed repeating the 1990-2000 conditions 10-fold. Four configurations were used to create simulations covering 1990-2013, although to validate INFERNO only the 1997-2010 period was analysed. The first three use CRU-NCEP meteorology with each of our three ignitions modes (see Sect. 2.1.1); constant ignitions (mode 1), prescribed lightning and constant anthropogenic ignitions (mode 2), and both natural and anthropogenic ignitions varying with prescribed lightning and population density (mode 3 ). The fourth simulation assumes mode 1 (constant ignitions), while meteorology is prescribed from WFDEI and precipitation from GPCC.

Evaluation was performed against the published data for GFEDv3, FINNv1, Global Fire Assimilation System (GFAS) and GFEDv4. We also used the data from GFEDv4s (http: //globalfiredata.org, manuscript in preparation) and GFEDv4 (Giglio et al., 2013) to calculate grid-specific emissions and burnt area. The GFED passes satellite observation of burnt area through the Carnegie-Ames-Stanford Approach
(CASA) biogeochemical model in order to obtain emissions from open burning. GFEDv4 (Giglio et al., 2013) innovates on GFEDv3 (Giglio et al., 2010) mainly through an updated algorithm to retrieve burnt area from MODIS satellite products and an increased spatial and temporal resolution, to $0.25^{\circ}$ and daily resolution (this resolution was assessed in Mangeon et al., 2015). Meanwhile GFEDv4s also includes the contribution from small fires (Randerson et al., 2012). The Fire Inventory from NCAR version 1.0 (FINNv1; Wiedinmyer et al., 2011) provides high-resolution (both temporal and spatial) global emissions of trace gas and particle emissions from open burning of biomass. It focuses on rapid availability and assimilation in real-time forecast and follows a similar process to GFED to estimate emission, but its burnt area is obtained directly from fire pixel using land cover (Wiedinmyer et al., 2011). The GFAS (Kaiser et al., 2012), unlike the aforementioned products, directly assess emissions from satellite-observed fire radiative power more apt at detecting small fires and avoiding the uncertainty of biogeochemical models.

\section{Results}

Maps of the burnt area and emitted carbon are displayed in Fig. 2, their resolution is 192 longitude by 145 latitude grid cells $\left(1.875^{\circ} \times 1.24^{\circ}\right)$. The results from INFERNO used a configuration with CRU-NCEP meteorology and the third ignition mode: interactive lighting and anthropogenic ignitions. We compare our results with downscaled means from GFED. INFERNO accurately diagnoses total fire occurrence 

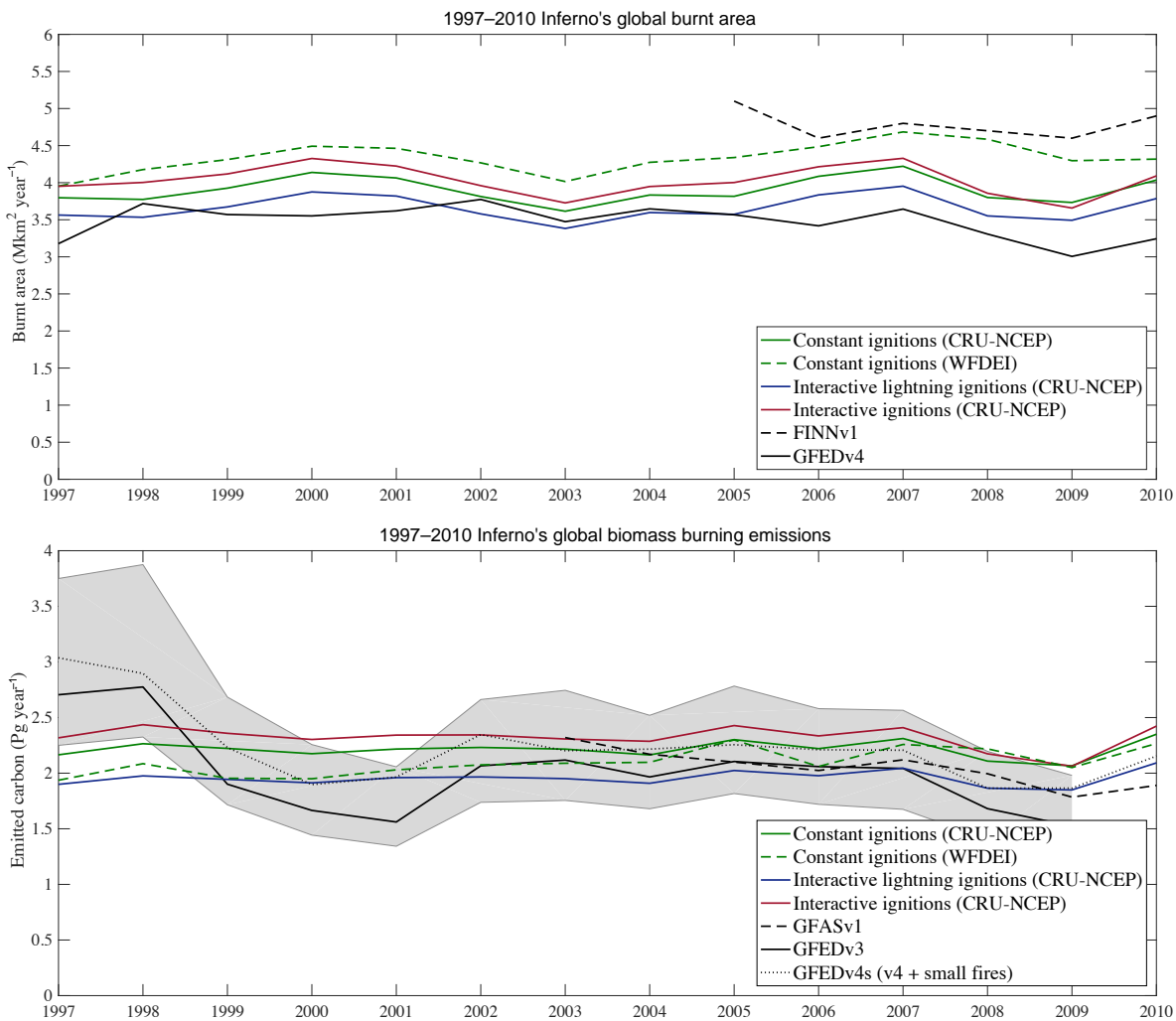

Figure 3. 1997-2010 biomass burning emissions and burnt area predicted by INFERNO. Two driving data sets were used, CRU-NCEP (solid lines) and WFDEI (green dotted line). Observations are shown in black (MODIS-based estimates). The grey shading represents 1 standard deviation within GFEDv3's estimates.

and emissions over the 1997-2010 period: we found a spatial correlation of $R=0.66$ for burnt area and $R=0.59$ for emitted carbon, both passing the $t$ test with $95 \%$ significance. In addition, regional mean yearly budgets are compared with GFED in Table B1. Compared to GFEDv4, we notice INFERNO estimates higher burnt area in all regions apart from Australia and New Zealand, and southern hemisphere Africa. Meanwhile emitted carbon is underestimated in boreal regions and equatorial Asia, but overestimated in most other regions (significantly in Southern Hemisphere America). Over the studied period, C4 grass were the main contributors to burnt area in INFERNO (a mean 2.34 million $\mathrm{km}^{2}$ year ${ }^{-1}$ ), meanwhile broadleaf evergreen trees (tropical) led to the most emitted carbon (a mean $1.48 \mathrm{Pg}$ year $\left.^{-1}\right)$. GFEDv4 projects the grid-box with maximum burnt area within the Central African Republic (87\% of grid fraction burnt per year), while INFERNO finds a maximum burnt area of $57 \%$, slightly to the north (south-east of Lake Tchad). The discrepancy is much larger for emissions, with a maximum emitted carbon of $1.47 \mathrm{~kg} \mathrm{~m}^{-2}$ year $^{-1}$ in Indonesia predicted by GFEDv4s, against $0.4 \mathrm{~kg} \mathrm{~m}^{-2}$ year $^{-1}$ for INFERNO, in Angola. These results could be expected, as INFERNO focuses on capturing global biomass burning, it will not represent such extremes of burning; furthermore, the immense emitted carbon observed in Indonesia follows from undiagnosed peat fires. INFERNO's approach to burnt area only considers trees, grass and shrub cover and was determined heuristically; meanwhile, Hantson et al. (2014) found global fire size was mostly influenced by precipitation, aridity and human activity (population density and croplands). Further parameterizations for fire size exist (e.g. Hantson et al., 2015, 2016), which could improve INFERNO burnt area estimates while maintaining simplicity and traceability.

Figure 3 shows the modelled global annual average biomass burning emissions and burnt area from 1997 to 2010. The three ignition methods are evaluated: fully interactive ignitions (red) predict the highest carbon emissions while interactive lightning with constant human ignitions (blue) the lowest. WFDEI was observed to lead to more biomass burning emissions in tropical forest areas (and in particular the borders of rainforests), while CRU-NCEP favoured burning in near-desert areas (the Sahel, India and south American grasslands). We expect this result to be significantly influenced by differences in precipitation (GPCC for WFDEI runs and CRU for CRU-NCEP; Schneider et al., 2013).

Comparisons to FINNv1, GFEDv4, GFASv1 and GFEDv3 were restricted to their budgets published in Kaiser et 
Table 2. Mean yearly emission budgets in Peta-grams of emitted carbon and mean yearly burnt area budgets in million $\mathrm{km}^{2}$ for the $1997-2010$ period. Latitudes were bound to beyond $50^{\circ}$ (high latitudes), 35 to $50^{\circ}$ (mid-latitudes), 15 to $35^{\circ}$ (low latitudes) and below $15^{\circ}$ (equatorial). Four configurations of INFERNO are presented, with CRU-NCEP and WFDEI driving meteorology coupled with three ignition modes: mode 1 indicates constant anthropogenic and lightning ignitions, mode 2 is for constant anthropogenic with interactive lightning ignitions, and mode 3 for interactive lightning and anthropogenic ignitions.

\begin{tabular}{lrrrr}
\hline Emitted carbon $\left(\mathrm{PgC} \mathrm{year}^{-1}\right)$ & mode 1 CRU-NCEP & mode 1 WFDEI & mode 2 CRU-NCEP & mode 3 CRU-NCEP \\
\hline High latitudes & 0.087 & 0.096 & 0.082 & 0.091 \\
Mid-latitudes & 0.185 & 0.193 & 0.170 & 0.191 \\
Low latitudes & 0.716 & 0.624 & 0.627 & 0.591 \\
Equatorial & 1.157 & 1.130 & 1.021 & 1.385 \\
\hline Burnt area $\left(\mathrm{M} \mathrm{km}^{2}\right.$ year $\left.^{-1}\right)$ & mode 1 CRU-NCEP & mode 1 WFDEI & mode 2 CRU-NCEP & mode 3 CRU-NCEP \\
\hline High latitudes & 0.176 & 0.196 & 0.162 & 0.179 \\
Mid-latitudes & 0.485 & 0.557 & 0.445 & 0.531 \\
Low latitudes & 1.648 & 1.884 & 1.558 & 1.531 \\
Equatorial & 1.524 & 1.580 & 1.423 & 1.693 \\
\hline
\end{tabular}

al. (2012), van der Werf et al. (2010), Wiedinmyer et al. (2011) and Giglio et al. (2013) respectively. Meanwhile we calculated global emissions from GFEDv4s (http: //globalfiredata.org, revision of van der Werf et al., 2010, in preparation).

Biomass burning emissions and burnt area simulated by the model follow similar trends to GFEDv3, although with a smaller inter-annual variability in the model. Carbon emissions from all simulations fall within 1 standard deviation of GFEDv3, apart from 3 years: 1997, 1998 and 2001. Note that for these years, emissions in GFED were obtained from the lower-resolution AVHRR rather than MODIS. 1997 and 1998 were strong El Niño years during which droughts in equatorial Asia led to extreme emissions from land-clearing fires, a recurrent problem in the region (Field et al., 2009). Indeed in 1997, in the region contained between $20^{\circ} \mathrm{S}-$ $20^{\circ} \mathrm{N}$ and $90-160^{\circ} \mathrm{E}$ (or equatorial Asia), GFEDv3 estimate emissions of $1.07 \mathrm{PgC}$, while INFERNO (with CRU-NCEP and fully interactive ignitions) estimates $0.15 \mathrm{PgC}$. Unfortunately, peat is not modelled in JULES and thus neither is peat present in our fire scheme. It was estimated tropical peat fires alone produced an average of $0.1 \mathrm{PgC}$ per year from 1997 to 2009 , and $0.7 \mathrm{PgC}$ in 1997 in particular (van der Werf et al., 2010). Furthermore, 2002 and 2006 also saw important peat burning, with GFEDv3 estimating peat emissions of 0.16 and $0.21 \mathrm{PgC}$ respectively. In both of these years, the trend in INFERNO differs from GFEDv3's (stagnation in 2002 and decrease in 2006). Peat-lands can be significant in equatorial Asia but also boreal regions where their combustion leads to the release of long-stored carbon (Turetsky et al., 2015). In 1998 and 2001, the difference in emissions could not be attributed to a particular location. While fire emissions from Equatorial Asia were underestimated, GFEDv3 observed lower emissions over Africa compared to INFERNO, which seems to be the key driver of our discrepancies.
Table 2 shows the budgets for four latitudinal bands across the various simulations performed. The second ignition mode (constant anthropogenic and interactive lightning ignitions at any time and place) appears to consistently predict lower emissions and burnt area (with the exception of low latitudes). Furthermore, the main impact of using an ignition model that varies with both natural and anthropogenic ignitions is a reduction of fires at low (tropical and sub-tropical) latitudes, and an increase in equatorial regions. Indeed, when compared to constant ignitions (mode 1), interactive ignitions (mode 3 ) predict more emissions in forest encroachment regions (noticeably surrounding the Congo and Amazon rainforests), and less in heavily populated areas (Nigeria, India). Meanwhile, we observed interactive lightning ignitions (mode 2) significantly reduced burning in grasslandsavannah environments. We link this to the predominance of cloud-to-ground lightning strikes in a wet environment within the LIS-OTD data set (e.g. the Congo rainforest; Christian et al., 2003) and fewer strikes (and ignitions) in the more flammable grasslands and savannahs. These issues are visible in Fig. B1, which shows difference maps of the four model configurations, for 1997-2010 mean yearly totals. Equatorial and boreal regions include peat that leads to large fuel consumption, which is unaccounted for in JULES, suggesting that our model will inherently underestimate emissions from these regions.

Species-specific average emissions produced by the INFERNO scheme are shown in Table 3 in Tg per year for the 1997-2010 period. $\mathrm{CO}$ and $\mathrm{CH}_{4}$ appear to be produced in noticeably larger quantities than in observation-based emission estimates. This hints at an overrepresentation of smouldering-type combustion. In INFERNO this might be due to the emission factors used, or the type of vegetation burnt.

In order to examine whether our flammability can represent fire occurrence, three other fire indices were diagnosed, 
Table 3. Average annual emission $\left(\mathrm{Tg}_{\text {year }}{ }^{-1}\right)$ for INFERNO with the interactive ignition mode and CRU-NCEP reanalysis (3 - CRU-NCEP) and the constant ignition mode and WFDEI reanalysis (1 - WFDEI), comparison to GFASv1 (Kaiser et al., 2012), GFEDv3 (van der Werf et al., 2010) and FINNv1 (Wiedinmyer et al., 2011) is provided.

\begin{tabular}{lrrrrrr}
\hline Global emission $\left(\right.$ Tg year $\left.^{-1}\right)$ & $\mathrm{CO}_{2}$ & $\mathrm{CO}$ & $\mathrm{CH}_{4}$ & $\mathrm{NO}_{x}$ & $\mathrm{BC}$ & $\mathrm{OC}$ \\
\hline INFERNO & & & & & & \\
3-CRU-NCEP & 7510.7 & 455.5 & 26.5 & 12.8 & 2.6 & 26.3 \\
1- WFDEI & 7149.8 & 429.3 & 24.8 & 12.2 & 2.4 & 24.9 \\
GFASv1 & 6906.7 & 351.5 & 19.0 & 9.5 & 2.0 & 18.2 \\
GFEDv3 & 6508.3 & 331.1 & 15.7 & 9.4 & 2.0 & 17.6 \\
FINNv1 & 7322.8 & 372.5 & 18.2 & 12.5 & 2.2 & 23 \\
\hline
\end{tabular}

Table 4. Temporal correlation coefficients $(R)$ of annual means (1997-2010) shown for four latitudinal bands. $R$ coefficients were obtained between either of the three simulated fire indices or INFERNO's burnt area (ubiquitous ignitions - ignition mode 1, using CRU-NCEP meteorology) and burnt area from GFEDv4 (Giglio et al., 2013). Italics mean the correlation was not significant ( $p$ value above 0.05). We restrict our analysis to grid-boxes in which GFEDv4 observed burning. Latitudes were bound to: beyond $50^{\circ}$ (high latitudes), 35 to $50^{\circ}$ (mid-latitudes), 15 to $35^{\circ}$ (low latitudes) and below $15^{\circ}$ (equatorial).

\begin{tabular}{lrrrr}
\hline $\begin{array}{l}R \text { coefficient } \\
\text { (with GFEDv4 burnt area) }\end{array}$ & $\begin{array}{r}\text { INFERNO } \\
\text { Burnt area }\end{array}$ & $\begin{array}{r}\text { Nesterov } \\
\text { Index }\end{array}$ & $\begin{array}{r}\text { McArthur } \\
\text { Index }\end{array}$ & $\begin{array}{r}\text { Canadian } \\
\text { Index }\end{array}$ \\
\hline Global & 0.649 & 0.088 & -0.009 & 0.266 \\
High latitudes & 0.476 & 0.522 & -0.005 & 0.519 \\
Mid-latitudes & 0.179 & -0.006 & 0.069 & 0.060 \\
Low latitudes & 0.603 & 0.476 & 0.499 & 0.480 \\
Equatorial & 0.689 & 0.239 & 0.354 & 0.392 \\
\hline
\end{tabular}

namely the McArthur, Nesterov and Canadian fire indices. These indices were obtained seamlessly during the model runs, therefore utilizing the same meteorological and hydrological driving variables, and the same vegetation conditions. Their predictions were regressed with GFEDv4 1997-2010 annual burnt area (Giglio et al., 2013). This analysis relies on the assumption that fire indices can be used as a proxy for the variability of fire occurrence and spread, and eventually of burnt area (not the magnitude). Only areas that had been observed to burn sometime between 1997 and 2010 were sampled; to avoid accounting for high fire indices in non-vegetated areas such as the Sahara.

Table 4 shows the result of our analysis. Ignitions followed mode 1: in this mode ignitions are constant; therefore, the only variability in burnt area (and performance) is due to INFERNO's flammability scheme. The McArthur index performs poorly at high latitudes (it was made for Australia), but outperforms the other indices in low latitude regions. The Canadian and Nesterov indices correlate best with observed burnt area in high latitude regions (for which they were developed). Altogether, INFERNO's burnt area appears to follow observed burnt area better than the sole usage of a fire index.

\section{Conclusion}

Through a minimalistic approach we propose a parameterization for fire occurrence of appropriate complexity for application at large spatial scales within an ESM context: the INteractive Fire and Emission algoRithm for Natural envirOnments (INFERNO). It directly only varies according to precipitation (and resulting soil moisture), temperature and humidity, and indirectly it utilises vegetation. It is also capable of explicitly simulating ignitions using lightning and anthropogenic information. While our scheme manages to represent fire occurrence on large scales (both spatial and temporal), it performs best at low latitudes. INFERNO's burnt area scheme appears superior to the use of fire indices alone (Nesterov, McArthur and basic Canadian) for capturing annual burnt area variations, and thus one form of fire impact. However, due to the nature of our analysis (fire danger and burnt area remain different quantities) this does not imply INFERNO should supersede fire weather indices for operational purposes, neither has our algorithm been built for numerical weather prediction or seasonal fire danger forecasting.

Nonetheless, our current simulations suggest the variability in emissions is underestimated by INFERNO, in particular the impact of the 1997-1998 El Niño and the subsequent La Niña, which may be attributable to the lack of representation of peat in the model, critical to biomass burn- 
ing in equatorial Asia and boreal areas. The use of different present-day meteorological data sets has an important impact on the magnitude and variability of our diagnostics. Using WFDEI-GPCC rather than CRU-NCEP led to more burnt area but lower fuel consumption and eventually less emitted carbon (this follows from grasslands burning rather than forests). Vegetation zone interfaces were key to this difference. Similarly, lightning appears to more frequently ignite fires in wet environments (rainforests) while flammable environments (savannah, grasslands) with rarer lightning are sensitive to the presence of an anthropogenic ignition source. Including a scheme to parameterise human impacts appears to significantly reduce fires in heavily populated areas, while favouring their encroachment of rainforests (the vicinity of which are an anthropogenic ignition "sweet spot" in our parameterization). Nevertheless, there is much uncertainty attributed to human induced emissions and effects on fire regime (Marlon et al., 2008; Thonicke et al., 2010). Accordingly, we include different modes to examine the impact of ignitions (human or natural) in INFERNO.

The implementation of INFERNO within the Met Office's Unified Model and its significance for present-day atmospheric composition and climate will be investigated in a separate paper. To close the vegetation-fire feedback, INFERNO will eventually need to remove carbon from vegetation and to include tree mortality. While a strength of the model is its minimalistic approach, the scheme holds potential for im- provements. For instance, litter influences flammability but only live vegetation leads to emissions while in reality litter significantly contributes to observed fuel consumption (van Leeuwen et al., 2014). Similarly, we predict that the inclusion of peat within JULES would improve its fire diagnostics, especially for locations with large fuel consumptions (e.g. equatorial Asia and boreal climates; van der Werf et al., 2010). Given the predictability of emissions from peat fires in relation to precipitation (van der Werf et al., 2008), this would be a promising area of exploration. The value of this model being its simplicity and linearity, any improvements to INFERNO should follow this vision; complex parameterizations are better suited for process-based fire schemes (e.g. Lasslop et al., 2014; Li et al., 2013, p. 1).

\section{Code availability}

Information on the JULES land surface model can be found at http://jules-lsm.github.io/. INFERNO is included in JULES $\mathrm{v} 4.5$ and is included in this documentation. The JULES source code can be accessed via the Met Office's science repository (requires registration): https://code. metoffice.gov.uk/trac/jules. In particular, the version of the code used to produce the outputs included in this study can be accessed at https://code.metoffice.gov.uk/trac/jules/browser/ main/branches/dev/stephanemangeon/vn4.3.1_inferno. 


\section{Appendix A}

This appendix contains additional information relating to the INFERNO scheme.
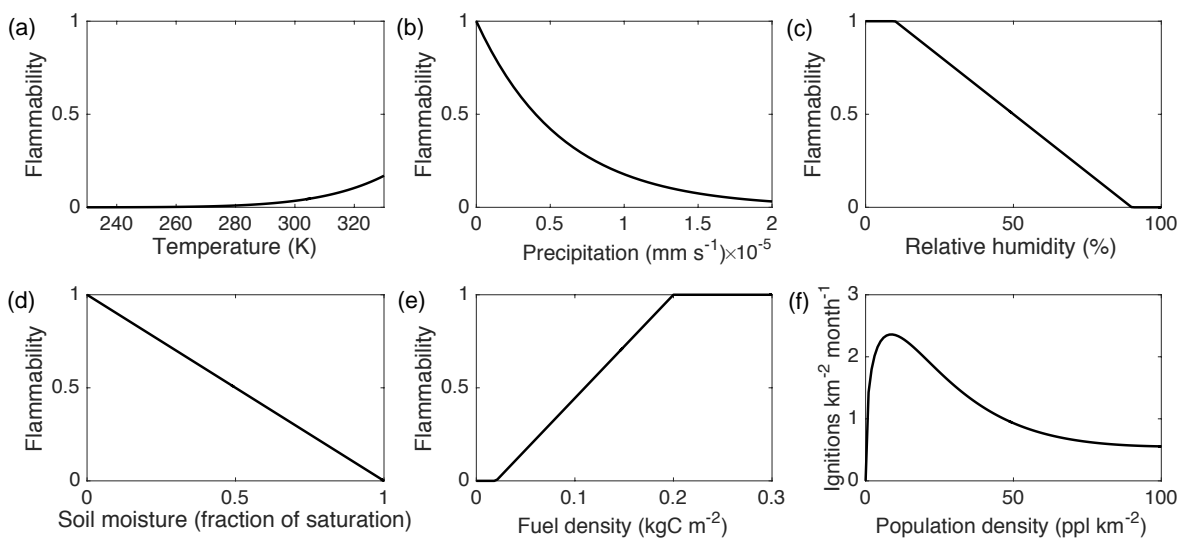

Figure A1. The mathematical functions used for individual dependencies of INFERNO on key driving variables for flammability (a, b, $\mathbf{c}$ d, e) and ignitions (f), within the range of reasonable Earth observations. Note the population density only influences the model output if ignition mode 3 is selected (interactive lightning and human ignition).

Table A1. The key JULES PFT-specific parameters for allometry and vegetation carbon used in our simulations (Clark et al., 2011).

\begin{tabular}{lrrrl}
\hline & $\begin{array}{r}\text { Specific leaf } \\
\text { density } \sigma_{1} \\
\left(\mathrm{~kg} \mathrm{C} \mathrm{m}^{-2}\right)\end{array}$ & $\begin{array}{r}\text { Allometric } \\
\text { coefficient } a_{\mathrm{wl}} \\
\left(\mathrm{kg} \mathrm{C} \mathrm{m}^{-2}\right)\end{array}$ & $\begin{array}{r}\text { Allometric } \\
\text { exponent }\end{array}$ & $\begin{array}{l}\text { Associated } \\
\text { fire biome in } \\
\text { Akagi et al. (2011) }\end{array}$ \\
\hline Broadleaf evergreen tree (tropical) & 0.0375 & 0.65 & 1.667 & tropical forests \\
Broadleaf evergreen tree (temperate) & 0.0375 & 0.65 & 1.667 & temperate forests \\
Broadleaf deciduous tree & 0.0375 & 0.65 & 1.667 & tropical forests \\
Needleleaf evergreen tree & 0.1 & 0.65 & 1.667 & temperate forests \\
Needleleaf deciduous tree & 0.1 & 0.75 & 1.667 & boreal forests \\
C3 grass & 0.025 & 0.005 & 1.667 & temperate forests \\
C4 grass & 0.05 & 0.005 & 1.667 & savannah and grasslands \\
Evergreen shrub & 0.05 & 0.10 & 1.667 & temperate forests \\
Deciduous shrub & 0.05 & 0.10 & 1.667 & boreal forests \\
\hline
\end{tabular}

Table A2. The characteristics of the Canadian's Fire Weather Index's three fuel moisture codes.

\begin{tabular}{llrrr}
\hline & Type of fuel & $\begin{array}{r}\text { Dry weight } \\
\left(\mathrm{kg} \mathrm{m}^{-2}\right)\end{array}$ & $\begin{array}{r}\text { Time lag } \\
\text { (days) }\end{array}$ & $\begin{array}{r}\text { Water capacity } \\
(\mathrm{mm})\end{array}$ \\
\hline $\begin{array}{l}\text { Fine fuel moisture code } \\
\text { Duff moisture code }\end{array}$ & $\begin{array}{l}\text { Litter and other fine fuels } \\
\text { Loosely compacted decomposing } \\
\text { organic matter } \\
\text { Deep layer of compact organic mat- } \\
\text { ter }\end{array}$ & 5 & $2-3$ & 0.6 \\
& & 25 & 52 & 15 \\
& & & 100 \\
\hline
\end{tabular}




\section{Appendix B}

This appendix contains additional results illustrating the dependence of INFERNO with ignitions and its performance on a regional basis.
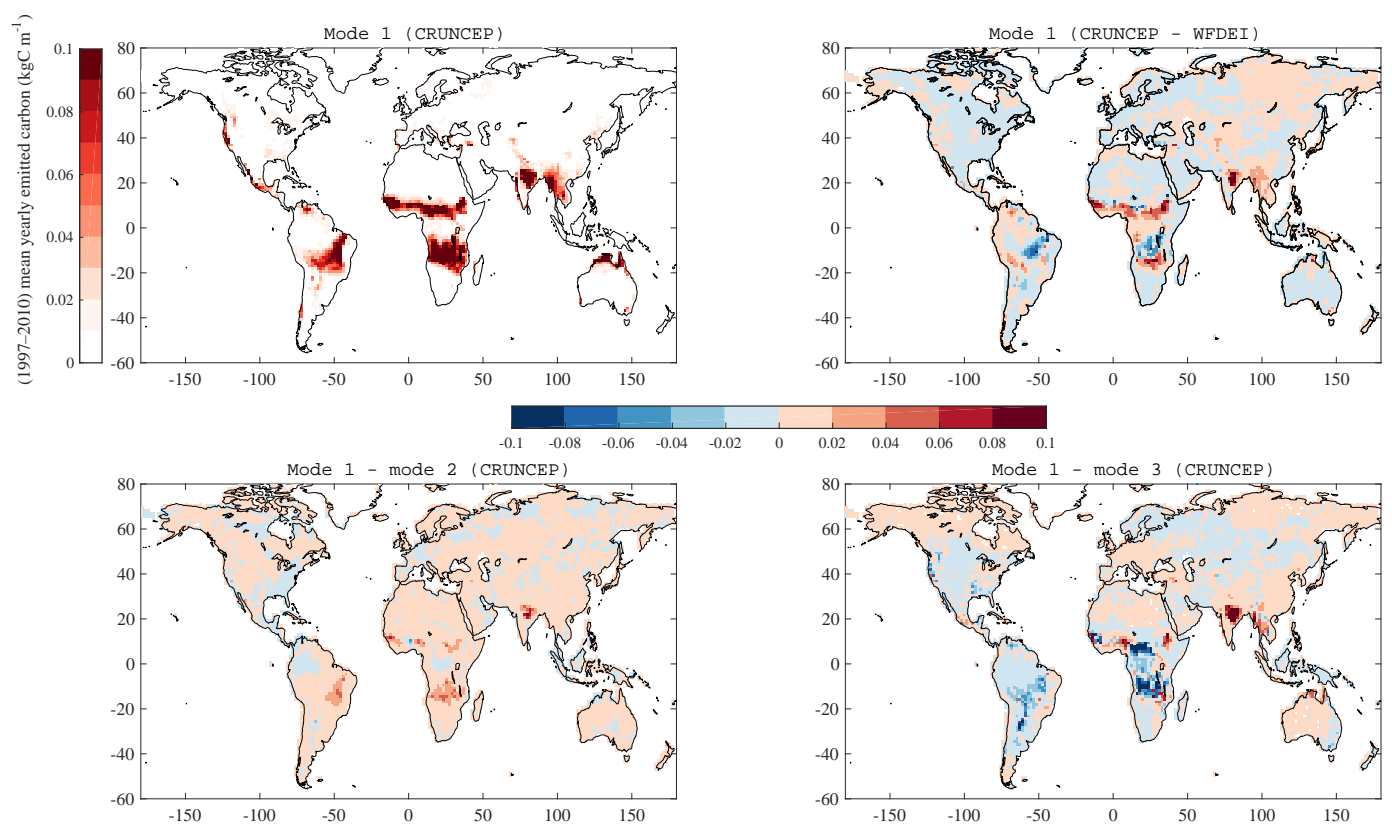

Figure B1. Emitted carbon difference maps between the four runs performed to analyse the sensitivity of INFERNO to ignitions (our three ignition modes; see Sect. 2.1.1) and meteorology (CRU-NCEP and WFDEI-GPCC).

Table B1. Regional budgets according to the standard GFED regions (van der Werf et al., 2010).

\begin{tabular}{lrrrrr}
\hline & \multicolumn{2}{c}{$\begin{array}{c}\text { Mean yearly burnt } \\
\text { area (in Mha) }\end{array}$} & & \multicolumn{2}{c}{$\begin{array}{c}\text { Mean yearly emitted } \\
\text { carbon (in TgC) }\end{array}$} \\
\cline { 2 - 3 } \cline { 5 - 6 } GFED standard regions & 2.2 & 5.2 & & 54 & 37 \\
GFEDv4 & INFERNO $^{\mathrm{b}}$ & & GFED3 $^{\mathrm{c}}$ & INFERNO $^{\mathrm{b}}$ \\
\hline Boreal North America & 1.8 & 29.9 & & 9 & 106 \\
Temperate North America & 1.8 & 7.9 & & 20 & 45 \\
Central America & 2.6 & 4.0 & & 22 & 51 \\
Northern Hemisphere South America & 18.7 & 68.3 & & 271 & 483 \\
Southern Hemisphere South America & 0.7 & 5.0 & & 4 & 29 \\
Europe & 0.8 & 12.3 & & 2 & 19 \\
Middle East & 117.7 & 120.4 & & 481 & 533 \\
Northern Hemisphere Africa & 125.0 & 57.6 & & 557 & 610 \\
Southern Hemisphere Africa & 5.6 & 9.7 & & 128 & 55 \\
Boreal Asia & 13.6 & 23.8 & & 36 & 50 \\
Central Asia & 7.0 & 29.6 & & 103 & 170 \\
Southeast Asia & 1.6 & 0.5 & & 191 & 10 \\
Equatorial Asia & 50.2 & 30.2 & & 135 & 96 \\
Australia and New Zealand & & & & &
\end{tabular}

a GFEDv4 mean yearly burnt area from Giglio et al. (2013), from 1997 to $2011 .^{\text {b }}$ INFERNO mean yearly burnt area and emitted carbon from 1997 to 2010, using ignition mode 3 (varying anthropogenic and natural ignitions) and CRU-NCEP driving meteorology. ${ }^{\mathrm{c}}$ GFED3 mean yearly emitted carbon from van der Werf et al. (2010) from 1997 to 2009. 
Author contributions. Apostolos Voulgarakis supervised the scientific design of INFERNO and the writing of this article. Gerd Folberth also supervised these aspects, with an emphasis on technical aspects of INFERNO in relation to the Met Office's Unified Model. Richard Gilham contributed to the technical design of the model and its implementation and led with the writing on fire indices. Anna Harper contributed to the design of INFERNO in relation to the vegetation scheme's recent development, helped with the analysis of vegetation biases in the study's results and led with the writing on the vegetation scheme. Stephen Sitch contributed throughout the writing, analysis and the scientific design of this study.

Acknowledgements. We wish to thank Robert Field, Pierre Friedlingstein, Stephen Hardwick, Sandy Harrison, Colin Prentice, Eddie Robertson and Andy Wiltshire for their inputs in the development and design of INFERNO; Olga Pechony, Greg Faluvegi and Drew Shindell for sharing their work on a fire parameterization. Stephen Sitch acknowledges the support of the Natural Environment Research Council (NERC) South AMerican Biomass Burning Analysis (SAMBBA) project grant code NE/J010057/1. The lead author gracefully thanks the Natural Environment Research Council (NERC, UK) and the UK Met Office for ongoing financial support, as well as the European Commission's Marie Curie Actions International Research Staff Exchange Scheme (IRSES) for past support under the REQUA project.

Edited by: J. Williams

Reviewed by: two anonymous referees

\section{References}

Akagi, S. K., Yokelson, R. J., Wiedinmyer, C., Alvarado, M. J., Reid, J. S., Karl, T., Crounse, J. D., and Wennberg, P. O.: Emission factors for open and domestic biomass burning for use in atmospheric models, Atmos. Chem. Phys., 11, 4039-4072, doi:10.5194/acp-11-4039-2011, 2011.

Andreae, M. O. and Merlet, P.: Emission of trace gases and aerosols from biomass burning, Global Biogeochem. Cy., 15, 955-966, doi:10.1029/2000GB001382, 2001.

Arora, V. K. and Boer, G. J.: Fire as an interactive component of dynamic vegetation models, J. Geophys. Res.-Biogeo., 110, G02008, doi:10.1029/2005JG000042, 2005.

Best, M. J., Pryor, M., Clark, D. B., Rooney, G. G., Essery, R. L. H., Ménard, C. B., Edwards, J. M., Hendry, M. A., Porson, A., Gedney, N., Mercado, L. M., Sitch, S., Blyth, E., Boucher, O., Cox, P. M., Grimmond, C. S. B., and Harding, R. J.: The Joint UK Land Environment Simulator (JULES), model description Part 1: Energy and water fluxes, Geosci. Model Dev., 4, 677-699, doi:10.5194/gmd-4-677-2011, 2011.

Bistinas, I., Harrison, S. P., Prentice, I. C., and Pereira, J. M. C.: Causal relationships versus emergent patterns in the global controls of fire frequency, Biogeosciences, 11, 5087-5101, doi:10.5194/bg-11-5087-2014, 2014.

Bond, W. J. and Keeley, J. E.: Fire as a global "herbivore": the ecology and evolution of flammable ecosystems, Trends Ecol. Evol., 20, 387-394, doi:10.1016/j.tree.2005.04.025, 2005.
Bowman, D. M., Murphy, B. P., Boer, M. M., Bradstock, R. A., Cary, G. J., Cochrane, M. A., Fensham, R. J., Krawchuk, M. A., Price, O. F., and Williams, R. J.: Forest fire management, climate change, and the risk of catastrophic carbon losses, Front. Ecol. Environ., 11, 66-67, doi:10.1890/13.WB.005, 2013.

Bowman, D. M. J. S., Balch, J. K., Artaxo, P., Bond, W. J., Carlson, J. M., Cochrane, M. A., D’Antonio, C. M., DeFries, R. S., Doyle, J. C., Harrison, S. P., Johnston, F. H., Keeley, J. E., Krawchuk, M. A., Kull, C. A., Marston, J. B., Moritz, M. A., Prentice, I. C., Roos, C. I., Scott, A. C., Swetnam, T. W., Werf, G. R. van der and Pyne, S. J.: Fire in the Earth System, Science, 324, 481-484, doi:10.1126/science.1163886, 2009.

Christian, H. J., Blakeslee, R. J., Boccippio, D. J., Boeck, W. L., Buechler, D. E., Driscoll, K. T., Goodman, S. J., Hall, J. M., Koshak, W. J., Mach, D. M., and Stewart, M. F.: Global frequency and distribution of lightning as observed from space by the Optical Transient Detector, J. Geophys. Res.-Atmos., 108, 4005, doi:10.1029/2002JD002347, 2003.

Chuvieco, E., Giglio, L., and Justice, C.: Global characterization of fire activity: toward defining fire regimes from Earth observation data, Glob. Change Biol., 14, 1488-1502, 2008.

Clark, D. B., Mercado, L. M., Sitch, S., Jones, C. D., Gedney, N., Best, M. J., Pryor, M., Rooney, G. G., Essery, R. L. H., Blyth, E., Boucher, O., Harding, R. J., Huntingford, C., and Cox, P. M.: The Joint UK Land Environment Simulator (JULES), model description - Part 2: Carbon fluxes and vegetation dynamics, Geosci. Model Dev., 4, 701-722, doi:10.5194/gmd-4-701-2011, 2011.

Cox, P. M.: Description of the TRIFFID dynamic global vegetation model, Technical Note 24, Hadley Centre, United Kingdom Meteorological Office, Bracknell, UK, available at: http: //www.metoffice.gov.uk/media/pdf/9/h/HCTN_24.pdf (last access: 10 September 2015), 2001.

Cox, P. M., Betts, R. A., Bunton, C. B., Essery, R. L. H., Rowntree, P. R., and Smith, J.: The impact of new land surface physics on the GCM simulation of climate and climate sensitivity, Clim. Dynam., 15, 183-203, doi:10.1007/s003820050276, 1999.

Dolman, J. A. and Gregory, D.: The Parametrization of Rainfall Interception In GCMs, Q. J. Roy. Meteor. Soc., 118, 455-467, doi:10.1002/qj.49711850504, 1992.

Field, R. D., van der Werf, G. R., and Shen, S. S. P.: Human amplification of drought-induced biomass burning in Indonesia since 1960, Nat. Geosci., 2, 185-188, doi:10.1038/ngeo443, 2009.

Forestry Canada: Development and structure of the Canadian Forest Fire Behavior Prediction System, available at: http://cfs.nrcan.gc. ca/publications?id=10068 (last access: 8 January 2016), 1992.

Fosberg, M. A., Cramer, W., Brovkin, V., Fleming, R., Gardner, R., Gill, A. M., Goldammer, J. G., Keane, R., Koehler, P., Lenihan, J., Neilson, R., Sitch, S., Thornicke, K., Venevski, S., Weber, M. G., and Wittenberg, U.: Strategy for a Fire Module in Dynamic Global Vegetation Models, Int. J. Wildland Fire, 9, 79-84, 1999.

Giglio, L., Randerson, J. T., van der Werf, G. R., Kasibhatla, P. S., Collatz, G. J., Morton, D. C., and DeFries, R. S.: Assessing variability and long-term trends in burned area by merging multiple satellite fire products, Biogeosciences, 7, 1171-1186, doi:10.5194/bg-7-1171-2010, 2010.

Giglio, L., Randerson, J. T., and van der Werf, G. R.: Analysis of daily, monthly, and annual burned area using the fourth- 
generation global fire emissions database (GFED4), J. Geophys. Res.-Biogeo., 118, 317-328, doi:10.1002/jgrg.20042, 2013.

Hantson, S., Pueyo, S., and Chuvieco, E.: Global fire size distribution is driven by human impact and climate, Glob. Ecol. Biogeogr., 24, 77-86, doi:10.1111/geb.12246, 2014.

Hantson, S., Lasslop, G., Kloster, S., and Chuvieco, E.: Anthropogenic effects on global mean fire size, Int. J. Wildland Fire, 24, 589-596, doi:10.1071/WF14208, 2015.

Hantson, S., Pueyo, S., and Chuvieco, E.: Global fire size distribution: from power law to log-normal, Int. J. Wildland Fire, 25, 403-412, doi:10.1071/WF15108, 2016.

Harper, A. B., Cox, P. M., Friedlingstein, P., Wiltshire, A. J., Jones, C. D., Sitch, S., Mercado, L. M., Groenendijk, M., Robertson, E., Kattge, J., Bönisch, G., Atkin, O. K., Bahn, M., Cornelissen, J., Niinemets, Ü., Onipchenko, V., Peñuelas, J., Poorter, L., Reich, P. B., Soudzilovskaia, N. A., and Bodegom, P. V.: Improved representation of plant functional types and physiology in the Joint UK Land Environment Simulator (JULES v4.2) using plant trait information, Geosci. Model Dev., 9, 2415-2440, doi:10.5194/gmd-9-2415-2016, 2016.

Huntrieser, H., Schumann, U., Schlager, H., Höller, H., Giez, A., Betz, H.-D., Brunner, D., Forster, C., Pinto Jr., O., and Calheiros, R.: Lightning activity in Brazilian thunderstorms during TROCCINOX: implications for $\mathrm{NO}_{x}$ production, Atmos. Chem. Phys., 8, 921-953, doi:10.5194/acp-8-921-2008, 2008.

Hurtt, G. C., Chini, L. P., Frolking, S., Betts, R. A., Feddema, J., Fischer, G., Fisk, J. P., Hibbard, K., Houghton, R. A., Janetos, A., Jones, C. D., Kindermann, G., Kinoshita, T., Goldewijk, K. K., Riahi, K., Shevliakova, E., Smith, S., Stehfest, E., Thomson, A., Thornton, P., van Vuuren, D. P., and Wang, Y. P.: Harmonization of land-use scenarios for the period 1500-2100: 600 years of global gridded annual land-use transitions, wood harvest, and resulting secondary lands, Climatic Change, 109, $117-$ 161, doi:10.1007/s10584-011-0153-2, 2011.

Johnston, F. H., Henderson, S. B., Chen, Y., Randerson, J. T., Marlier, M., DeFries, R. S., Kinney, P., Bowman, D. M. J. S., and Brauer, M.: Estimated Global Mortality Attributable to Smoke from Landscape Fires, Environ. Health Perspect., 120, 695-701, doi:10.1289/ehp.1104422, 2012.

Kaiser, J. W., Heil, A., Andreae, M. O., Benedetti, A., Chubarova, N., Jones, L., Morcrette, J.-J., Razinger, M., Schultz, M. G., Suttie, M., and van der Werf, G. R.: Biomass burning emissions estimated with a global fire assimilation system based on observed fire radiative power, Biogeosciences, 9, 527-554, doi:10.5194/bg-9-527-2012, 2012.

Lamarque, J.-F., Bond, T. C., Eyring, V., Granier, C., Heil, A., Klimont, Z., Lee, D., Liousse, C., Mieville, A., Owen, B., Schultz, M. G., Shindell, D., Smith, S. J., Stehfest, E., Van Aardenne, J., Cooper, O. R., Kainuma, M., Mahowald, N., McConnell, J. R., Naik, V., Riahi, K., and van Vuuren, D. P.: Historical (1850-2000) gridded anthropogenic and biomass burning emissions of reactive gases and aerosols: methodology and application, Atmos. Chem. Phys., 10, 7017-7039, doi:10.5194/acp10-7017-2010, 2010.

Lamlom, S. H. and Savidge, R. A.: A reassessment of carbon content in wood: variation within and between 41 North American species, Biomass Bioenergy, 25, 381-388, doi:10.1016/S09619534(03)00033-3, 2003.
Lasslop, G., Thonicke, K., and Kloster, S.: SPITFIRE within the MPI Earth system model: Model development and evaluation, J. Adv. Model. Earth Syst., 6, 740-755, doi:10.1002/2013MS000284, 2014.

Lasslop, G., Hantson, S., and Kloster, S.: Influence of wind speed on the global variability of burned fraction: a global fire model's perspective, Int. J. Wildland Fire, 24, 989-1000, 2015.

Le Quéré, C., Moriarty, R., Andrew, R. M., Peters, G. P., Ciais, P., Friedlingstein, P., Jones, S. D., Sitch, S., Tans, P., Arneth, A., Boden, T. A., Bopp, L., Bozec, Y., Canadell, J. G., Chini, L. P., Chevallier, F., Cosca, C. E., Harris, I., Hoppema, M., Houghton, R. A., House, J. I., Jain, A. K., Johannessen, T., Kato, E., Keeling, R. F., Kitidis, V., Klein Goldewijk, K., Koven, C., Landa, C. S., Landschützer, P., Lenton, A., Lima, I. D., Marland, G., Mathis, J. T., Metzl, N., Nojiri, Y., Olsen, A., Ono, T., Peng, S., Peters, W., Pfeil, B., Poulter, B., Raupach, M. R., Regnier, P., Rödenbeck, C., Saito, S., Salisbury, J. E., Schuster, U., Schwinger, J., Séférian, R., Segschneider, J., Steinhoff, T., Stocker, B. D., Sutton, A. J., Takahashi, T., Tilbrook, B., van der Werf, G. R., Viovy, N., Wang, Y.-P., Wanninkhof, R., Wiltshire, A., and Zeng, N.: Global carbon budget 2014, Earth Syst. Sci. Data, 7, 47-85, doi:10.5194/essd-7-47-2015, 2015.

Li, F., Zeng, X. D., and Levis, S.: A process-based fire parameterization of intermediate complexity in a Dynamic Global Vegetation Model, Biogeosciences, 9, 2761-2780, doi:10.5194/bg-9-27612012, 2012.

Li, F., Levis, S., and Ward, D. S.: Quantifying the role of fire in the Earth system - Part 1: Improved global fire modeling in the Community Earth System Model (CESM1), Biogeosciences, 10, 2293-2314, doi:10.5194/bg-10-2293-2013, 2013.

Li, F., Bond-Lamberty, B., and Levis, S.: Quantifying the role of fire in the Earth system - Part 2: Impact on the net carbon balance of global terrestrial ecosystems for the 20th century, Biogeosciences, 11, 1345-1360, doi:10.5194/bg-11-1345-2014, 2014.

Mangeon, S., Field, R. D., Fromm, M., McHugh, C., and Voulgarakis, A.: Satellite versus ground-based estimates of burned area: A comparison between MODIS based burned area and fire agency reports over North America in 2007, Anthropocene Rev., doi:10.1177/2053019615588790, online first, 2015.

Marlier, M. E., DeFries, R. S., Voulgarakis, A., Kinney, P. L., Randerson, J. T., Shindell, D. T., Chen, Y., and Faluvegi, G.: El Nino and health risks from landscape fire emissions in southeast Asia, Nat. Clim. Change, 3, 131-136, doi:10.1038/nclimate1658, 2013.

Marlon, J. R., Bartlein, P. J., Carcaillet, C., Gavin, D. G., Harrison, S. P., Higuera, P. E., Joos, F., Power, M. J., and Prentice, I. C.: Climate and human influences on global biomass burning over the past two millennia, Nat. Geosci., 1, 697-702, doi:10.1038/ngeo313, 2008.

Nesterov, V.: Forest fires and methods of fire risk determination, Russ. Goslesbumizdat Mosc., 1949.

Noble, I. R., Gill, A. M., and Bary, G. A. V.: McArthur's firedanger meters expressed as equations, Aust. J. Ecol., 5, 201-203, doi:10.1111/j.1442-9993.1980.tb01243.x, 1980.

Pechony, O. and Shindell, D. T.: Fire parameterization on a global scale, J. Geophys. Res.-Atmos., 114, D16115, doi:10.1029/2009JD011927, 2009. 
Pechony, O. and Shindell, D. T.: Driving forces of global wildfires over the past millennium and the forthcoming century, P. Natl. Acad. Sci., doi:10.1073/pnas.1003669107, 2010.

Peng, S., Ciais, P., Chevallier, F., Peylin, P., Cadule, P., Sitch, S., Piao, S., Ahlström, A., Huntingford, C., Levy, P., Li, X., Liu, Y., Lomas, M., Poulter, B., Viovy, N., Wang, T., Wang, X., Zaehle, S., Zeng, N., Zhao, F., and Zhao, H.: Benchmarking the seasonal cycle of $\mathrm{CO}_{2}$ fluxes simulated by terrestrial ecosystem models, Glob. Biogeochem. Cy., 29, 2014GB004931, doi:10.1002/2014GB004931, 2015.

Pfeiffer, M., Spessa, A., and Kaplan, J. O.: A model for global biomass burning in preindustrial time: LPJ-LMfire (v1.0), Geosci. Model Dev., 6, 643-685, doi:10.5194/gmd-6-643-2013, 2013.

Prentice, S. A. and Mackerras, D.: The Ratio of Cloud to Cloud-Ground Lightning Flashes in Thunderstorms, J. Appl. Meteorol., 16, 545-550, doi:10.1175/15200450(1977)016<0545:TROCTC >2.0.CO;2, 1977.

Randerson, J. T., Chen, Y., van der Werf, G. R., Rogers, B. M., and Morton, D. C.: Global burned area and biomass burning emissions from small fires, J. Geophys. Res.-Biogeo., 117, G04012, doi:10.1029/2012JG002128, 2012.

Schneider, U., Becker, A., Finger, P., Meyer-Christoffer, A., Ziese, M., and Rudolf, B.: GPCC's new land surface precipitation climatology based on quality-controlled in situ data and its role in quantifying the global water cycle, Theor. Appl. Climatol., 115, 15-40, doi:10.1007/s00704-013-0860-x, 2013.

Sirakoff, C.: A correction to the equations describing the McArthur forest fire danger meter, Aust. J. Ecol., 10, 481-481, doi:10.1111/j.1442-9993.1985.tb00909.x, 1985.

Sitch, S., Smith, B., Prentice, I. C., Arneth, A., Bondeau, A., Cramer, W., Kaplan, J. O., Levis, S., Lucht, W., Sykes, M. T., Thonicke, K. and Venevsky, S.: Evaluation of ecosystem dynamics, plant geography and terrestrial carbon cycling in the LPJ dynamic global vegetation model, Glob. Change Biol., 9, 161-185, doi:10.1046/j.1365-2486.2003.00569.x, 2003.

Sitch, S., Friedlingstein, P., Gruber, N., Jones, S. D., MurrayTortarolo, G., Ahlström, A., Doney, S. C., Graven, H., Heinze, C., Huntingford, C., Levis, S., Levy, P. E., Lomas, M., Poulter, B., Viovy, N., Zaehle, S., Zeng, N., Arneth, A., Bonan, G., Bopp, L., Canadell, J. G., Chevallier, F., Ciais, P., Ellis, R., Gloor, M., Peylin, P., Piao, S. L., Le Quéré, C., Smith, B., Zhu, Z., and Myneni, R.: Recent trends and drivers of regional sources and sinks of carbon dioxide, Biogeosciences, 12, 653679, doi:10.5194/bg-12-653-2015, 2015.

Spracklen, D. V., Logan, J. A., Mickley, L. J., Park, R. J., Yevich, R., Westerling, A. L., and Jaffe, D. A.: Wildfires drive interannual variability of organic carbon aerosol in the western U.S. in summer, Geophys. Res. Lett., 34, L16816, doi:10.1029/2007GL030037, 2007.

Thonicke, K., Venevsky, S., Sitch, S., and Cramer, W.: The role of fire disturbance for global vegetation dynamics: coupling fire into a Dynamic Global Vegetation Model, Glob. Ecol. Biogeogr., 10, 661-677, doi:10.1046/j.1466-822X.2001.00175.x, 2001.

Thonicke, K., Spessa, A., Prentice, I. C., Harrison, S. P., Dong, L., and Carmona-Moreno, C.: The influence of vegetation, fire spread and fire behaviour on biomass burning and trace gas emissions: results from a process-based model, Biogeosciences, 7, 1991-2011, doi:10.5194/bg-7-1991-2010, 2010.
Tosca, M. G., Randerson, J. T., and Zender, C. S.: Global impact of smoke aerosols from landscape fires on climate and the Hadley circulation, Atmos. Chem. Phys., 13, 5227-5241, doi:10.5194/acp-13-5227-2013, 2013.

Turetsky, M. R., Benscoter, B., Page, S., Rein, G., van der Werf, G. R., and Watts, A.: Global vulnerability of peatlands to fire and carbon loss, Nat. Geosci., 8, 11-14, doi:10.1038/ngeo2325, 2015.

van der Werf, G., Dempewolf, J., Trigg, S. N., Randerson, J. T., Kasibhatla, P. S., Giglio, L., Murdiyarso, D., Peters, W., Morton, D. C., Collatz, G. J., Dolman, A. J., and DeFries, R. S.: Climate regulation of fire emissions and deforestation in equatorial Asia, P. Natl. Acad. Sci., 105, 20350-20355, doi:10.1073/pnas.0803375105, 2008.

van der Werf, G. R., Morton, D. C., DeFries, R. S., Olivier, J. G. J., Kasibhatla, P. S., Jackson, R. B., Collatz, G. J., and Randerson, J. T.: $\mathrm{CO}_{2}$ emissions from forest loss, Nat. Geosci., 2, 737-738, doi:10.1038/ngeo671, 2009.

van der Werf, G. R., Randerson, J. T., Giglio, L., Collatz, G. J., Mu, M., Kasibhatla, P. S., Morton, D. C., DeFries, R. S., Jin, Y., and van Leeuwen, T. T.: Global fire emissions and the contribution of deforestation, savanna, forest, agricultural, and peat fires (19972009), Atmos. Chem. Phys., 10, 11707-11735, doi:10.5194/acp10-11707-2010, 2010.

van Leeuwen, T. T., van der Werf, G. R., Hoffmann, A. A., Detmers, R. G., Rücker, G., French, N. H. F., Archibald, S., Carvalho Jr., J. A., Cook, G. D., de Groot, W. J., Hély, C., Kasischke, E. S., Kloster, S., McCarty, J. L., Pettinari, M. L., Savadogo, P., Alvarado, E. C., Boschetti, L., Manuri, S., Meyer, C. P., Siegert, F., Trollope, L. A., and Trollope, W. S. W.: Biomass burning fuel consumption rates: a field measurement database, Biogeosciences, 11, 7305-7329, doi:10.5194/bg-11-7305-2014, 2014.

Van Wagner, C. E. and Pickett, T. L.: Equations and FORTRAN program for the Canadian Forest Fire Weather Index System, available at: http://www.cfs.nrcan.gc.ca/publications/?id=19973 (last access: 8 January 2016), 1985.

Venevsky, S., Thonicke, K., Sitch, S., and Cramer, W.: Simulating fire regimes in human-dominated ecosystems: Iberian Peninsula case study, Glob. Change Biol., 8, 984-998, doi:10.1046/j.13652486.2002.00528.x, 2002.

Voulgarakis, A. and Field, R. D.: Fire Influences on Atmospheric Composition, Air Quality and Climate, Curr. Pollut. Rep., 1, 7081, doi:10.1007/s40726-015-0007-z, 2015.

Voulgarakis, A., Savage, N. H., Wild, O., Braesicke, P., Young, P. J., Carver, G. D., and Pyle, J. A.: Interannual variability of tropospheric composition: the influence of changes in emissions, meteorology and clouds, Atmos. Chem. Phys., 10, 2491-2506, doi:10.5194/acp-10-2491-2010, 2010.

Voulgarakis, A., Marlier, M. E., Faluvegi, G., Shindell, D. T., Tsigaridis, K., and Mangeon, S.: Interannual variability of tropospheric trace gases and aerosols: The role of biomass burning emissions, J. Geophys. Res.-Atmos., 120, 7157-7173, doi:10.1002/2014JD022926, 2015.

Weedon, G. P., Balsamo, G., Bellouin, N., Gomes, S., Best, M. J., and Viterbo, P.: The WFDEI meteorological forcing data set: WATCH Forcing Data methodology applied to ERAInterim reanalysis data, Water Resour. Res., 50, 7505-7514, doi:10.1002/2014WR015638, 2014. 
Wiedinmyer, C., Akagi, S. K., Yokelson, R. J., Emmons, L. K., AlSaadi, J. A., Orlando, J. J., and Soja, A. J.: The Fire INventory from NCAR (FINN): a high resolution global model to estimate the emissions from open burning, Geosci. Model Dev., 4, 625641, doi:10.5194/gmd-4-625-2011, 2011.

Yue, C., Ciais, P., Cadule, P., Thonicke, K., Archibald, S., Poulter, B., Hao, W. M., Hantson, S., Mouillot, F., Friedlingstein, P., Maignan, F., and Viovy, N.: Modelling the role of fires in the terrestrial carbon balance by incorporating SPITFIRE into the global vegetation model ORCHIDEE - Part 1: simulating historical global burned area and fire regimes, Geosci. Model Dev., 7, 2747-2767, doi:10.5194/gmd-7-2747-2014, 2014. 